\title{
Breeding birds of "Nomentum" nature reserve (central Italy): a forest remnant landscape surrounded by an agro-urbanized matrix
}

\author{
Corrado Battisti ${ }^{1 *}$, Veridiana Barucci ${ }^{2}$, Valeria Concettini ${ }^{1}$, \\ Giuseppe Dodaro ${ }^{2}$, Francesca Marini ${ }^{1}$
}

\begin{abstract}
We carried out a standardized breeding bird atlas of "Nomentum" nature reserve (central Italy), located in a fragmented hilly forest near a large urbanized area (Rome). In order to obtain information about local composition, occurrence, distribution and richness, we correlated data with environmental heterogeneity and vegetation structure variables. We recorded 58 species in $48500 \times 500 \mathrm{~m}$-wide atlas units, with Parus major, Corvus cornix, Turdus merula, Sylvia atricapilla, Sylvia melanocephala, as the most occurring in frequency (> 80\%). Although synanthropic species represent only slightly more than $20 \%$ in number and urban environments are relatively reduced in size, these species show a higher mean occurrence when compared to mosaic species, despite the fact that these last are higher in species number and mosaic habitats are widely diffused. Local urbanization may disrupt communities, facilitating opportunistic species linked to these environments (i.e. synanthropic) and inducing a decline in mosaic species. Moreover, the homogenization induced by anthropization could, at least partially, explain the lack of correlation between habitat diversity and species richness, at local scale. Finally, tree density and diameter do not affect total bird richness at this spatial grain/scale. In this regard, further analyses could test for possible correlations between habitat variables and single ecological guilds.
\end{abstract}

Keywords urbanization, synanthropic species, forest species, mosaic species, homogenization, habitat heterogeneity.

Riassunto - Uccelli nidificanti della Riserva naturale "Nomentum": un paesaggio forestale residuale inserito in una matrice agricola in fase di urbanizzazione.

Si riportano i dati ottenuti da un atlante standardizzato degli uccelli nidificanti nella riserva naturale "Nomentum" (Italia centrale), collocata in un paesaggio collinare a dominanza forestale ad elevato grado

${ }^{1}$ Torre Flavia LTER (Long Term Ecological Research) Station, Protected area Service, Città Metropolitana di Roma, Viale G. Ribotta 41/43, 00144 Roma, Italia.

E-mail: valeconce@yahoo.it f.marini@cittametropolitanaroma.gov.it

${ }^{2}$ Sustainable Development Foundation, Via Garigliano 61a, 00198

Roma, Italia.

E-mail: veridianabarucci@gmail.com dodaro@susdef.it

* Corresponding author: c.battisti@cittametropolitanaroma.it

(C) 2022 Corrado Battisti, Veridiana Barucci, Valeria Concettini, Giuseppe Dodaro, Francesca Marini

Received for publication: 6 April 2021

Accepted for publication: 26 May 2021

Online publication: 20 May 2022 di frammentazione, in prossimità di una vasta area urbanizzata (Roma), al fine di ottenere dati sulla composizione, presenza, distribuzione e ricchezza specifica. Sono state registrate 58 specie in 48 unità di rilevamento di ampiezza 500x500. Parus major, Corvus cornix, Turdus merula, Sylvia atricapilla e Sylvia melanocephala hanno mostrato la frequenza di copertura più elevata $(>80 \%)$. Sebbene le specie sinantropiche rappresentino solo poco più del $20 \%$ in numero e gli ambienti urbani siano di dimensioni relativamente ridotte, queste specie mostrano una presenza media più elevata rispetto alle specie legate ai mosaici ambientali, nonostante il fatto che queste ultime siano in maggior numero e gli ambienti a mosaico mostrino una ampia distribuzione. L'urbanizzazione a scala locale può perturbare le comunità, facilitando specie opportunistiche e sinantropiche legate a questi ambienti e favorendo un declino delle specie di mosaico. Inoltre, l'omogeneizzazione indotta dall'antropizzazione potrebbe, almeno in parte, spiegare la mancanza di correlazione tra diversità di habitat e ricchezza di specie, osservata a scala locale. La densità e il diametro degli alberi non influenzano la ricchezza totale degli uccelli nidificanti a questa grana/ scala spaziale. A questo proposito, ulteriori analisi potrebbero testare possibili correlazioni tra variabili di habitat e single guilds (corporazioni) ecologiche.

Keywords urbanizzazione, specie sinantropiche, specie forestali, specie di mosaico ambientale, omogenizzazione, eterogeneità ambientale.

\section{INTRODUCTION}

Forest ecosystems of the plains and hilly areas of central Italy are markedly fragmented and embedded in a heterogeneous and anthropized landscape matrix: this can have effects on the bird communities both at faunal and structural level (Battisti, 2001; Bianconi et al., 2003; Frank \& Battisti, 2005; Lorenzetti \& Battisti, 2006; Mortelliti et al., 2010; Arca et al., 2012). A large number of these remnant ecosystems are now included in protected areas: therefore, it is of relevant interest to study the local bird communities, obtaining quali-quantitative and spatially-referred data. In this regard, the Atlas of breeding birds - providing systematized information on the species occurrence, distribution and richness - can be a useful tool at different scales (Araújo et al., 2005). This knowledge can be used to define appropriate planning, management and conservation actions and strategies at species-, comunity- and ecosystem-level.

In central Italy, in the last decade, the number of such local atlases has been increasing with many examples available for protected areas (e.g., Guidi \& Battisti, 2010; Taffon et al., 2011; Quatrini et al., 2012; Marini et al., 2014; 
Brunelli et al., 2016; Sorace et al., 2017; Muratore et al., 2018; Ceccarelli et al., 2019; Sorace et al., 2019; Battisti et al., 2020). However, one of the most frequent biases of atlases is represented by the non-uniform research effort, which leads to a data unreliability, such as a over- or underestimated patterns of species distribution (see $\mathrm{Su}$ therland, 2006). For this reason, it has been highlighted the need to standardize the research effort per sampling unit (Donald \& Fuller, 1998; Sutherland, 2006). Consequently, the sampling protocols followed standardized approaches in order to obtain reliable data, for example, using the same number of researchers for sampling units, as well as standards at spatial (cells of equal size) and temporal level (uniform time per detection units; see Taffon et al., 2011; Marini et al., 2014; Battisti et al., 2020).

As part of the management of a regional protected natural area (Nomentum nature reserve), we carried out a standardized breeding bird atlas in order to obtain data about local occurrence, distribution and richness. Although this reserve has already been thoroughly investigated for many animal taxa (terrestrial molluscs: Crucitti et al., 2003; insects: Crucitti et al. 2004b; Crucitti et al., 2015; amphibians, reptiles and mammals: Crucitti et al., 2004a, 2005b; Crucitti \& Bufalieri, 2012; Doglio et al., 2013; see also Crucitti et al., 2013a), a quali-quantitative analysis of the composition and distribution of the breeding bird is not yet available, with the exception of some studies focused on the effects of forest fragmentation on sensitive species and guilds (Battisti et al., 2003, 2004, 2009; Lorenzetti \& Battisti, 2005, 2006, 2007; Taffon \& Battisti, 2003).

Since the patterns of frequency distribution of species could be deeply affected by the agricultural and urban anthropization, we obtained information both on the composition and distribution of breeding species and on the relationship between species richness vs. environmental heterogeneity and vegetation structure. More in particular, our aims were: 1) to describe the bird community and guilds of the nature reserve and 2) to assess how landscape and habitat features affect the composition of communities and guilds. In addition to providing local information, it may also have a more general interest since this nature reserve is located in a fragmented hilly forest near a large urbanized area of central Italy.

\section{STUDY AREA}

The "Nomentum" nature reserve (Regional Law n.29 / 1997), about 850 hectares wide, is sited in the north east sector of Rome metropolitan area (Mentana and Fonte Nuova Municipalities; IGM 144 III SE). The Reserve is located in a hilly clay system (between 60 and 200 meters a.s.1.), between the Campagna Romana, the Tiber river and pre-Apennines mountans (Lucretili, Cornicolani mts.; Crucitti, 2013). The Reserve is characterized by a landscape mosaic including remnant fragments of deciduous broad-leaved forests, embedded in an anthropized matrix with olive groves, cultivated and urbanized areas. In the last decades, the progressive expansion of the urban settlements has occurred to the detriment of the natural areas, which are reduced - especially the woods - in isolated patches (Rosati et al., 2010).
The soils are mainly of sandy-clayey type (Paolini \& Capecchi, 2004). From the phytoclimatic point of view, the "Nomentum" nature reserve is located in the Mediterranean transitional belt (Tiber valley and the system of foothills of the Apennines; Blasi, 1994; Vannicelli Casoni, 2004). For the vegetation aspects, the following typologies are noted: (i) the mesophilic forests (in the northern area, Macchia Trentani and Selva Cavalieri), consisting of Quercus cerris, Quercus robur, and Carpinus orientalis; (ii) patches of hygrophilous vegetation along the ditches and impluvium lines, characterized by the presence of Ulmus minor, Salix alba and Populus nigra and, locally, by reed bed patches at Phragmites australis and Arundo donax; (iii) the mixed thermophilic coppiced woods (in the southern area, Macchia Mancini) with Quercus cerris, $Q$. frainetto, $Q$. pubescens, Fraxinus ornus, Acer campestre and Ostrya carpinifolia; (iv) uncultivated areas and pastures, with Crataegus monogyna, Rubus ulmifolius, Ulmus minor, Ulmus glabra; finally, (v) in the urbanized areas ornamental, cultivated and hedges species occur, such as Olea europaea, Malus domestica, Prunus persica, Nerium oleander, Platanus $x$ acerifolia, Cedrus deodara, Cupressus sempervirens, Pinus pinea and Thuja orientalis (Guidi, 2004). Further details on the area in Crucitti et al. $(2000,2001)$.

\section{METHODS \\ Protocol}

A squared grid was over-imposed on the whole of study area (and on the immediately adjacent contexts). This grid was made up of $48500 \times 500 \mathrm{~m}$-wide survey units (S.U.) obtained by dividing each UTM unit $1 \times 1 \mathrm{~km}$ of the Regional Technical Map (scale 1: 10,000; Lazio Region, 1990; Fig. 1). In the 2019 spring period (from 7 March to 27 June), we randomly walked the sector of each S.U. twice during the breeding season (the first in March and April, the second in May and June). In each of the two times a 20-minute non-linear transect was performed, as representative as possible of the entire S.U. (Bibby et al., 2000; total effort: 40 minutes/S.U.; total research effort: approx: 1,900 minutes).

During each sampling every direct and indirect sighting of each presumably breeding species was recorded, obtaining a data of occurrence in any S.U. We have considered a species occurring in a S.U. whether at least one direct or indirect contact of the species was obtained in at least one session. We then accumulated the occurrence data obtained from the two sessions for each S.U. Species abundance data were not obtained. Nikon $8 \times 40$ and Leica 10x42 binoculars were used for bird species detection.

\section{DATA ANALYSIS \\ Distribution maps, frequencies of occurrence and guild characterization}

We obtained local distribution maps both for each breeding species and for the total species richness. For each species we obtained the number of S.U. occupied and the frequency on the total occurrences (fr occ, that is, n. S.U./48), a proxy of the local distribution of the species. The relative frequency of species occurrence was 


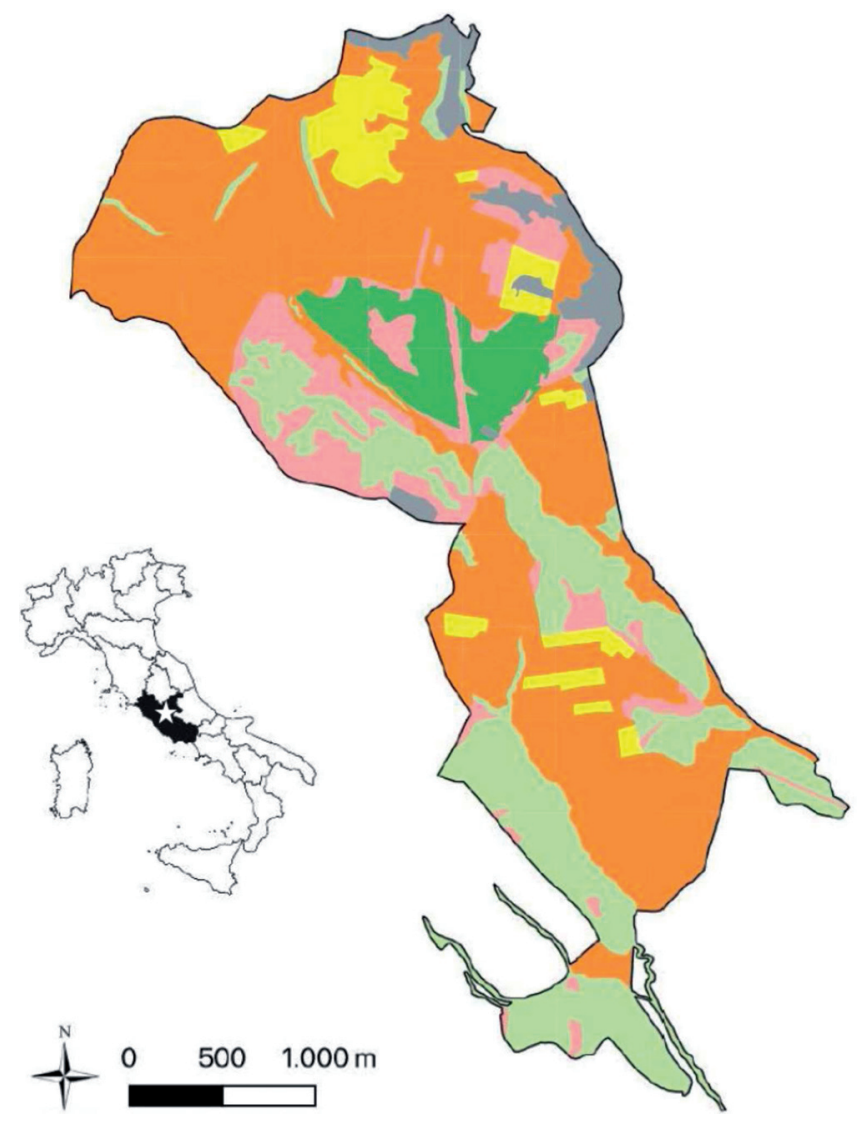

Fig. 2 - Map of the study area. Colors represent the different habitat types. In green: woods (dark green: high forests; light green: coppiced woods, characterized by mixed oak species including $Q$. cerris, $Q$. pubescens, $Q$. frainetto); orange: woody agricultural crops (olive groves, vineyards, orchards); yellow: arable land sensu lato (annual and/or perennial and with the presence of pastures); pink: shrubby-edge areas (ecotonal habitats with isolated trees and shrubs such as Rubus ulmifolius); grey: urban environments (included road infrastructures and recreational areas). Star represents the location of study site at regional scale. / Cartografia dell'area di studio. I colori rappresentano le diverse tipologie di habitat. In verde: aree forestali (verde scuro: fustaia; verde chiaro: boschi cedui, caratterizzati da querceti misti con Q. cerris, $Q$. pubescens e $Q$. frainetto); arancio: ambienti agricoli con legnose agrarie (oliveti, vigneti, frutteti); giallo: aree coltivate in senso lato (a diverso regime agricolo, anche con presenza di pascoli e incolti); rosa: aree marginali e arbustive (ambienti ecotonali con alberi isolati e arbusteti con Rubus ulmifolius); grigio: ambienti urbani (incluse infrastrutture stradali e aree classificate come a scopo ricreativo). La stella indica la collocazione dell'area di studio a scala nazionale. also calculated (fr, i.e. the ratio between the number of S.U. occupied by a species and the total number of species occurrences). This frequency data was used to obtain preliminary information on the spatial structure of the breeding community in the study area.

The breeding bird species were coarse-grained characterized grouping them into the following ecological categories (guilds): forest species (sensu lato: FOR); edge-mosaic, open-habitat and crop-land species (MOS); synanthropic species (SYN; see Tab. 1); following the ecological preferences reported in Fornasari et al. (2010) and, for Latium, in Brunelli et al. (2011). For each guild, the average number of S.U. occupied and the frequency of the total occurrences were calculated. For the nomenclature and systematic order, reference was made to the recent check list of Italian birds (Baccetti et al., 2019).

\section{Habitat heterogeneity, vegetation structure and breeding bird richness}

For each S.U., the percentage frequency (fr) of land use was calculated using the Qgis software (version 2.14.22), selecting the following coarse-grained categories: coppice woods (characterized by mixed oak species including $Q$. cerris, $Q$. pubescens, $Q$. frainetto); woody agricultural crops (olive groves, vineyards, orchards); arable land (annual and / or perennial and with the presence of pastures); ecotonal habitats (isolated trees and shrubs such as Rubus ulmifolius, Crataeugus sp., and Prunus spinosa); urban environments (included road infrastructures and recreational areas; see Fig. 2).

From the land use/cover frequencies, an habitat heterogeneity index was obtained using the Shannon-Wiener diversity (entropy) index: $\mathrm{H}^{\prime}=-\Sigma$ fr $\ln \mathrm{fr}$, where fr = percentage frequency of land use of the i-th category (Shannon \& Weaver, 1949; Magurran, 2004).

In a sub-sector, corresponding to the forest core of the protected area reserve ("Trentani wood" and surrounding, classified as " $\mathrm{A}$ " zone of nature reserve of high conservation concern: centroid: $42^{\circ} 01^{\prime} 12.0^{\prime \prime} \mathrm{N} 12^{\circ} 38^{\prime} 01.9^{\prime} \mathrm{E}$ ) and including a representative sample of any habitat type (high forests, coppiced woods, and shrubby-edge areas; details in AA. VV., 1999; Buccomino et al., 2017), we also carried out a fine-grained analysis of the vegetation structure, selecting 13 S.U.). In each S.U. we randomly selected

Tab. 1 - Structural characteristics of tree vegetation (mean tree density and diameter and number of tree species) for the sub-area (see Methods, for details). High forest and coppiced woods: characterized by mixed oak species including Q. cerris, $Q$. pubescens, Q. frainetto; ecotones (shrubby-edge areas): ecotonal habitats (isolated trees and shrubs such as Rubus ulmifolius). / Caratteristiche strutturali della vegetazione arborea (densità media di alberi, diametro e numero di specie arboree) per la sub-area (vedi Metodi per i dettagli). Le fustaie e i boschi cedui sono caratterizzati da querceti misti con $Q$. cerris, $Q$. pubescens, $Q$. frainetto; gli ecotoni (ambienti arbustivi marginali) includono alberi isolati e arbusteti con Rubus ulmifolius.

\begin{tabular}{|l|c|c|c|c|}
\hline & High forest & Coppiced wood & Ecotones & KW test \\
\hline Mean tree density & $17.5 \pm 4.78$ & $20.64 \pm 10.23$ & $14.36 \pm 12.73$ & $7.030, \mathrm{p}=0.019$ \\
\hline Mean tree diameter & $32.98 \pm 11.79$ & $24.71 \pm 14.35$ & $27.77 \pm 17.29$ & $64.780, \mathrm{p}<0.001$ \\
\hline Tree species & 8 & 13 & 15 & \\
\hline
\end{tabular}




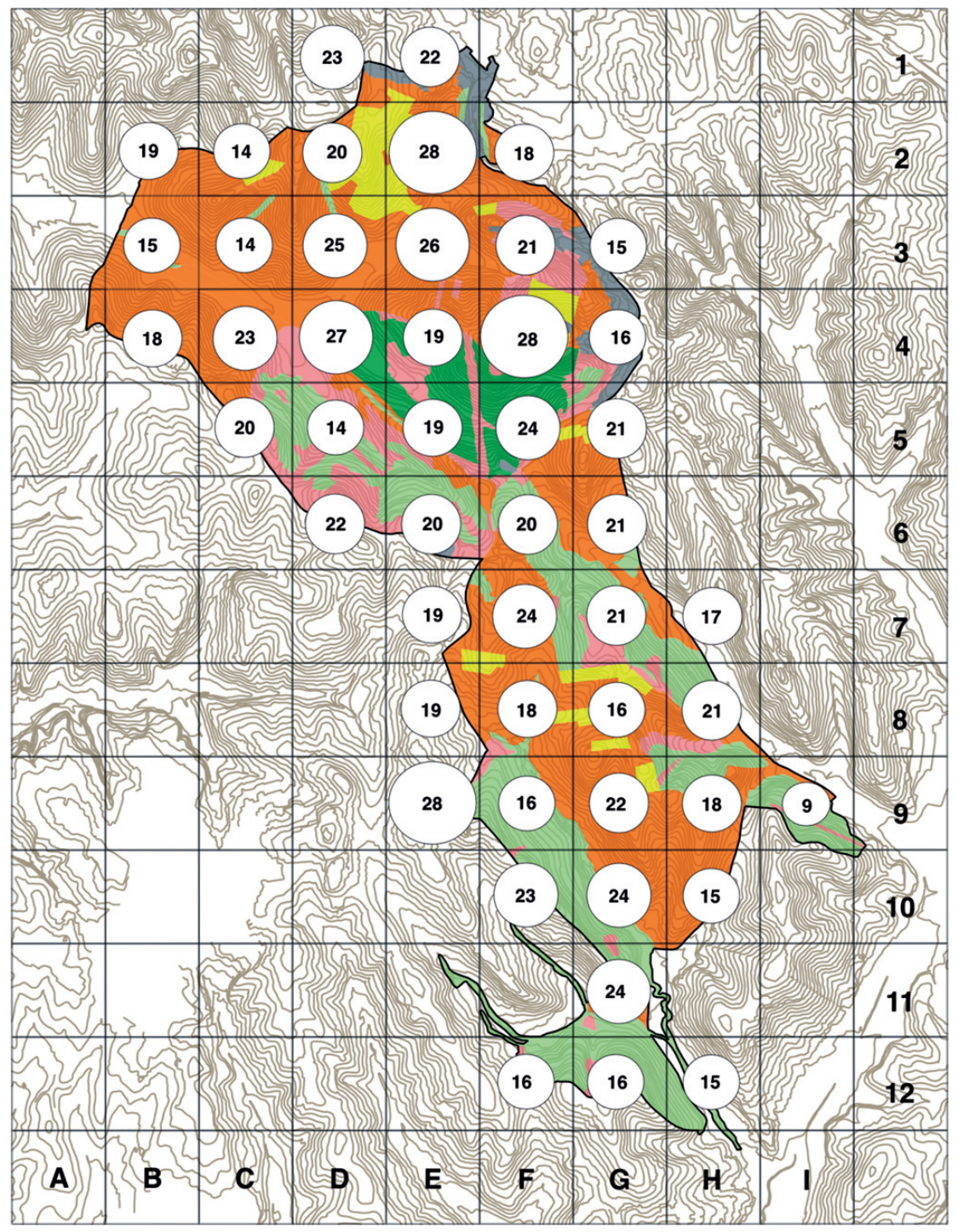

Fig. 2 - Map of breeding bird species richness for the "Nomentum" nature reserve. / Mappa della ricchezza di specie di uccelli nidificanti nella Riserva naturale "Nomentum".

five circular 400m²-wide plots (James \& Shugart, 1970; Deconchat \& Balent, 2001; total: 65 plots). In each plot all tree plants with a diameter $>7 \mathrm{~cm}$ were taxonomically identified and counted. For each of them, the diameter to the breast heigth $(1.30 \mathrm{~m}$ from the ground) was measured. From these measurements, the following parameters were obtained for each S.U.: tree species richness, mean tree density (n. plants/plot) and mean tree diameter (in $\mathrm{cm}$; Table 1). We used this sub-set of data to assess the role of vegetation structure in predict the bird species richness.

\section{Statistical analyses}

To test for differences among frequencies in both species number of different guilds and different habitat types, we used the $\chi^{2}$ test. Data on the structural variables of vegetation and land use cover were compared and correlated with data on breeding birds (both total and divided by guilds). To test for differences both in averaged values of number of occurrences and structural variables of vegeta- tion (plant density and diameter) among different guilds, we performed non-parametric comparison tests between un-paired mean values ( 2 cases: U Mann-Whitney test; > 2 cases: Kruskall-Wallis test). Habitat diversity indices have been correlated to the breeding species richness using a non-parametric test (Spearman's rank test, 2 tail; Dytham, 2011). We used the SPSS 13.0 software for Windows. Alpha level was set at 0.05 level.

\section{RESULTS \\ Distribution maps and frequency of occurrences}

We obtained 951 occurrences relating to 58 species of breeding birds (Table 2). The number of species/S.U. ranged from 9 to 28 (see map of species richness in Fig. 2). Five species (Parus major, Corvus cornix, Turdus merula, Sylvia atricapilla, Sylvia melanocephala) were the most widely distributed (percentage frequency of occurrence $>$ $80 \%)$. Localized species $(<20 \%)$ show the highest percentages in species number $(\mathrm{n}=25 ;>40 \%)$. 
Tab. 2 - Breeding bird species of the "Nomentum" nature reserve. Number of occurrences (n occ) and frequencies both on the total of occurrences (Fr tot) and on the total of S.U (FrSU; in bold: FrSU>0.50). Among brackets, the ecological guilds (FOR: forest species; MOS: mosaic species; SYN: synanthropic species). / Uccelli nidificanti nella Riserva naturale "Nomentum". Numero di presenze (n occ) e frequenze sia sul totale delle presenze (Fr tot) e sul totale delle Unità di rilevamento standard (S.U.; FrSU; in grassetto: FrSU>0.50). Tra parentesi, le corporazioni ecologiche (FOR: specie forestali; MOS: specie di mosaico ambientale; SYN: specie sinantropiche).

\begin{tabular}{|c|c|c|c|c|c|c|c|}
\hline Species (and guilds) & n occ & Frtot & Fr SU & Species (and guilds) & n occ & Frtot & Fr SU \\
\hline Parus major (FOR) & 46 & 0.048 & 0.96 & Cuculus canorus (FOR) & 12 & 0.013 & 0.25 \\
\hline Corvus cornix (SYN) & 45 & 0.047 & 0.94 & Regulus ignicapilla (FOR) & 11 & 0.012 & 0.23 \\
\hline Turdus merula (FOR) & 44 & 0.046 & 0.92 & Pica pica (MOS) & 10 & 0.011 & 0.21 \\
\hline Sylvia atricapilla (FOR) & 44 & 0.046 & 0.92 & Oriolus oriolus (FOR) & 10 & 0.011 & 0.21 \\
\hline Sylvia melanocephala (MOS) & 43 & 0.045 & 0.9 & Falco tinnunculus (MOS) & 9 & 0.009 & 0.19 \\
\hline Cyanistes caeruleus (FOR) & 38 & 0.04 & 0.79 & Luscinia megarhynchos (MOS) & 8 & 0.008 & 0.17 \\
\hline Serinus serinus (MOS) & 36 & 0.038 & 0.75 & Emberiza calandra (MOS) & 8 & 0.008 & 0.17 \\
\hline Passer domesticus (SYN) & 36 & 0.038 & 0.75 & Streptopelia turtur (FOR) & 7 & 0.007 & 0.15 \\
\hline Troglodytes troglodytes (FOR) & 33 & 0.035 & 0.69 & Hippolais polyglotta (MOS) & 7 & 0.007 & 0.15 \\
\hline Fringilla coelebs (FOR) & 33 & 0.035 & 0.69 & Garrulus glandarius (FOR) & 7 & 0.007 & 0.15 \\
\hline Carduelis chloris (MOS) & 32 & 0.034 & 0.67 & Sitta europaea (FOR) & 6 & 0.006 & 0.13 \\
\hline Hirundo rustica (SYN) & 30 & 0.032 & 0.63 & Monticola solitarius (SYN) & 6 & 0.006 & 0.13 \\
\hline Erithacus rubecula (FOR) & 27 & 0.028 & 0.56 & Saxicola torquatus (MOS) & 5 & 0.005 & 0.1 \\
\hline Streptopelia decaocto (SYN) & 26 & 0.027 & 0.54 & Psittacula krameri (SYN) & 4 & 0.004 & 0.08 \\
\hline Columba palumbus (FOR) & 26 & 0.027 & 0.54 & Motacilla alba (SYN) & 4 & 0.004 & 0.08 \\
\hline Dendrocopos major (FOR) & 25 & 0.026 & 0.52 & Passer montanus (SYN) & 3 & 0.003 & 0.06 \\
\hline Carduelis carduelis (SYN) & 24 & 0.025 & 0.5 & Corvus monedula (SYN) & 3 & 0.003 & 0.06 \\
\hline Picus viridis (FOR) & 22 & 0.023 & 0.46 & Carduelis cannabina (MOS) & 3 & 0.003 & 0.06 \\
\hline Certhia brachydactyla (FOR) & 22 & 0.023 & 0.46 & Apus apus (SYN) & 3 & 0.003 & 0.06 \\
\hline Phasianus colchicus (MOS) & 21 & 0.022 & 0.44 & Upupa epops (MOS) & 2 & 0.002 & 0.04 \\
\hline Columba livia dom. (SYN) & 21 & 0.022 & 0.44 & Merops apiaster (MOS) & 2 & 0.002 & 0.04 \\
\hline Aegithalos caudatus (FOR) & 21 & 0.022 & 0.44 & Dendrocopos minor (FOR) & 2 & 0.002 & 0.04 \\
\hline Sturnus vulgaris (SYN) & 20 & 0.021 & 0.42 & Buteo buteo (MOS) & 2 & 0.002 & 0.04 \\
\hline Cettia cetti (MOS) & 20 & 0.021 & 0.42 & Sylvia communis (MOS) & 1 & 0.001 & 0.02 \\
\hline Emberiza cirlus (MOS) & 17 & 0.018 & 0.35 & Phoenicurus ochruros (MOS) & 1 & 0.001 & 0.02 \\
\hline Phylloscopus collybita (FOR) & 16 & 0.017 & 0.33 & Jynx torquilla (FOR) & 1 & 0.001 & 0.02 \\
\hline Cisticola juncidis (MOS) & 16 & 0.017 & 0.33 & Coturnix coturnix (MOS) & 1 & 0.001 & 0.02 \\
\hline Sylvia cantillans (MOS) & 15 & 0.016 & 0.31 & Alauda arvensis (MOS) & 1 & 0.001 & 0.02 \\
\hline Delichon urbicum (SYN) & 12 & 0.013 & 0.25 & Accipiter nisus (FOR) & 1 & 0.001 & 0.02 \\
\hline
\end{tabular}

The local distribution maps of the species have been shown in Supporting information. Occasional observations outside the standard method were also obtained for Lanius collurio, Athene noctua, Myiopsitta monachus, all probably nesting in the Reserve. Vagrant (not locally breeding) species were also recorded during this study: Larus michaellis, Bubulcus ibis, Milvus migrans, Falco peregrinus (nesting in the surrounding; Pozzo del Merro near Sant'Angelo Romano; Battisti et al., 2017) and Phylloscopus sibilatrix and P. trochilus, these last using the Reserve as a stop-over site during migratory pass.
The guilds of forest and mosaic habitats showed the highest number of species (both $\mathrm{n}=22 ; 37.9 \%$ ) when compared to the guild of synanthropic species $(n=14$; $24.1 \%$ ). At the frequency level, forest species showed the highest significant values (about the 50\%; Table 3). Despite forest and mosaic habitats are largely more represented (they are found in $70 \%$ and $90 \%$ of SUs, respectively) in the Reserve, mosaic species showed the lowest values of mean distribution of occurrences (frequency $<30 \%$ on the total occurrences; Table 3). Differently, synanthropic species showed a larger averaged 
distribution when compared to mosaic species, although S.U. hosting urbanized habitats are low in frequency (about 20\%).

\section{Habitat heterogeneity, vegetation structure and breeding bird richness}

Habitat diversity indices H' in S.U. ranged from 0 to 1.512. There was no significant correlation between bird species richness and habitat diversity $\left(r_{s}=0.252, p=0.084\right.$; Spearman rank correlation test, 2 tail) with data showing a high variance (regression line: $\mathrm{S}=2.66 \mathrm{H}^{\prime}+18.03 ; \mathrm{R}^{2}=$ $0.064)$.

At vegetation structural level (1128 measured plants with dominance of Quercus cerris, $Q$. robur, $Q$. frainetto), we obtained a significant difference in the tree density among paired habitat types (high wood, coppiced wood, shrubby-edge areas; Table 1), with shrubby-edges showing a significantly lower density than both high forests $(\mathrm{U}=136 ; \mathrm{z}=-2.119 ; \mathrm{p}=0.034)$ and coppiced woods $(\mathrm{U}=134 ; \mathrm{z}=-2.539 ; \mathrm{p}=0.011)$. Coppiced woods and high forests were not significantly different $(\mathrm{U}=183$; $\mathrm{z}$ $=0.934 ; \mathrm{p}=0.350$; Mann-Whitney $\mathrm{U}$ test). As expected, mean tree diameter was significantly higher in high woods when compared to coppiced woods $(\mathrm{U}=52638.5$; z $=-8.214 ; \mathrm{p}<0.001)$ and with shrubby-edge areas $(\mathrm{U}=$ 43089; $z=-4.926 ; p<0.001$ ); differences between coppiced woods and shrubby-edge areas were not significant $(\mathrm{U}=66418 ; \mathrm{z}=-1.751 ; \mathrm{p}=0.080)$.

Bird species richness was not correlated neither to mean tree density $\left(r_{s}=0.101, p=0.742\right)$ nor to mean tree diameter $\left(\mathrm{r}_{\mathrm{s}}=-0.061, \mathrm{p}=0.843,2\right.$ tail $)$.

\section{DISCUSSION}

"Nomentum" nature reserve hosts breeding bird communities typical of agroforestry mosaics of central
Italy (e.g., Sarrocco et al., 2002; Frank \& Battisti, 2005; Lorenzetti \& Battisti, 2006) and this atlas improves previous published and unpublished knowledge (Battisti, 2001; Taffon \& Battisti, 2003; Giardini, 2004; Battisti, 2006; Brunelli et al., 2011; Giardini \& Battisti, 2012; Crucitti et al., 2013) and unpublished sources (Ornitho. it, iNaturalist.it and BioLazio - Società Romana di Scienze Naturali).

However, when grouping species in ecological guilds, our original data evidence how landscape urbanization greatly affected their spatial occurrence. Indeed, although synanthropic species represent only slightly more than $20 \%$ in number and urban environments are relatively reduced in size (approximately the $20 \%$ of S.U.), these species show a higher mean occurrence than mosaic ones, although the latter are more numerous and mosaic habitats are more widespread ( $>90 \%$ of S.U.).

The role of urbanization in disrupt bird communities and facilitating opportunistic species has been worldwide evidenced (e.g. Seress \& Liker, 2015), with several authors suggesting a role of these species as indicator of ongoing urbanization process (Guetté et al. 2017). As is known, urbanization is one of the main causes of biotic homogenization and change in the structure and functionality of bird communities (Blair, 2001; McKinney, 2006; Devictor et al., 2008). The results of our study seem to indicate that a similar process has begun in the Nomentum Reserve as well. Urban sprawl, which has caused the loss of rural and forest habitats and increased fragmentation, is favoring the spread of a few robust and widespread species ("adapters", "exploiters" and "urbanophiles", sensu Johnston, 2001) at the expense of many more specialized and less common species (Crooks et al., 2004; Blair, 2004; Blair \& Johnson, 2008).

Also, the decline of mosaic species has been largely underlined, both a local, national and continental level. In particular, many studies have highlighted the strong

Tab. 3 - Guild analysis (FOR: forest species, MOS: mosaic edge species; SYN: synanthropic species). N SU and Fr SU: respectively, number and frequency of SU (Standard Units) with at least 1 ha with the specific habitat type (FOR, MOS o SYN); $n$ occ and fr occ: respectively, total number of occurrences and relative frequency for each habitat guild; Mean occ: mean number of occurrences for each habitat guild, and s.d. standard deviation). Statistics: (1) $\chi^{2}$ test (d.f. 2), (2) Kruskall-Wallis test (d.f. 2). / Analisi a livello di corporazioni ecologiche: (FOR: specie forestali; MOS: specie di mosaico e di ambienti marginali; SYN: specie sinantropiche). N SU e Fr SU: rispettivamente, numero e frequenza delle SU (Unità di rilevamento standard) con almeno 1 ha ricadente negli specifici tipi di habitat selezionati (FOR, MOS o SYN); n occ e fr occ: rispettivamente, numero totale di presenze e frequenza relativa per ogni guild (corporazione ecologica); Mean occ: numero medio di presenze per ogni guild ecologica, e deviazione standard, s.d.). Statistiche: (1) test del $\chi^{2}$ test ( 2 gradi di libertà), (2) test di Kruskall-Wallis test (2 gradi di libertà).

\begin{tabular}{|l|c|c|c|c|c|c|}
\hline & \multicolumn{5}{|c|}{ Guilds } & \\
\hline & FOR & MOS & SYN & Tot & test & p \\
\hline N UR & 34 & 44 & 10 & 48 & & \\
\hline Fr UR & 70.83 & 91.67 & 20.83 & & $\chi^{2}=53.53(1)$ & $<0.001$ \\
\hline N occ & 454 & 260 & 237 & 951 & & \\
\hline Fr occ & 47.74 & 27.34 & 24.92 & 1 & $\chi^{2}=134.47(1)$ & $<0.001$ \\
\hline Mean occ (s.d.) & $20.64(14.54)$ & $11.82(12.18)$ & $16.93(13.98)$ & $16.40(13.87)$ & $\mathrm{H}=5.22(2)$ & 0.073 \\
\hline
\end{tabular}


decrease of farmland species in Italy (e.g. Gustin et al., 2010; Nardelli et al., 2015; Calvi et al., 2018; Brambilla, 2019; see also Gustin et al., 2019). The latest data from the longest-running farmland species monitoring program nationwide (Rete Rurale Nazionale \& Lipu, 2021) show that in the period 2000-2020 there was a drastic reduction in the overall value of the Farmland Bird Index (Gregory et al., 2005; Gregory \& van Strien, 2010) and in the populations of 16 of the 28 species typical of agricultural areas used in Italy for calculation of the index (Campedelli et al., 2012).

An even worse situation is found at the regional level, where the overall value of the index has decreased in the last 20 years by more than $40 \%$ and more than 50 $\%$ of the species monitored are in decline, particularly those related to mosaics. Our data reflects this condition: although agricultural areas are widespread in almost 60 $\%$ of the study area, some of the typical farmland species have never been contacted, although habitat types are suitable for them (e.g. Calandrella brachydactyla, Galerida cristata, Lanius senator) and two species have been detected in a single S.U. (Alauda arvensis and Lanius collurio, occasional observations, the last outside the standard method).

The few occurrences of farmland species in the Nomentum Reserve certainly depend on national dynamics and also on specific local conditions, such as the disturbance caused by land use change and the strong anthropization of the surrounding areas, a particularly incisive and much investigated factor (e.g. Szép et al., 2012; FilippiCodaccioni et al., 2008; Havlíček et al. 2021; for Italy: La Mantia et al., 2014; Velatta et al., 2016). For some fieldnesting species (e.g. Alauda arvensis) another limiting factor may be the strong heterogeneity of the territory, as these birds tend to avoid vertical structures such as forest edges (Berg et al., 2015).

One of the main predictors of species richness is environmental heterogeneity, i.e. habitat diversity, and this pattern was widely recognized worldwide in bird communities at local/regional scales (e.g. Rafe et al., 1985; Būhning-Gaese, 1997; Tews et al., 2004; Stein et al., 2014; see also the 'habitat heterogenity hypothesis: Connor \& McCoy, 1979). However, although a large proportion of the Reserve is characterized by mosaics with a large range in habitat diversity, we obtained only a weak correlation between habitat diversity and species richness, also controlling for the area effect. Probably (i) the narrow range in species richness, (ii) the fine-grained scale of atlas units when compared to bird-perceived scale of heterogeneity and, (iii) the role of anthropization and disturbances in homogeneize the differences among sites, could locally affected our pattern. Last but not least, the variable used to describe habitat heterogeneity (i.e. habitat diversity by Shannon-Wiener index), as it does not consider any spatially explicit attribute (patch shape and configuration, patchiness, edge ratio, etc.), may be a further factor affecting our results.

Although expected differences in tree density and diameter occur among habitat types due to different forest management (coppicing leads to the production of multiple suckers from each plant, so improving tree density in coppiced woods; Mattioli et al., 2008; del Río et al., 2014), these structural variables do not affect bird species richness at this spatial grain/scale. Probably at level of total number of species significant patterns are not evident, since different forest ecological guilds (e.g. shrub species, hole-nesting birds, forest generalists, edge species, etc.), here not considered, may be sensitive each one to specific ranges in mean tree density and mean tree diameter. Further analyses are necessary to analyze these guild-based relationships.

Local bird atlases, if made according to rigorous and effective protocols, represent a tool that protected areas must equip themselves with: in fact they provide an important qualitative and quantitative knowledge base useful for understanding spatial distribution of species and also specific phenomena such as biotic homogenization, helping to understand how and in which areas anthropogenic activities affect biodiversity (Devictor et al., 2007). Therefore, they are useful tools to define specific management and restorarion actions at community, guild or species level.

Further investigations may include a more in-depth analyses of relationships among ecological guilds (considering other criteria as trophic level, phenology, spatial niche, etc) and further fine-grained environmental variables (e.g., type of vegetation, degree of anthropization, etc.), so overcoming this first explorative spatial approach.

\section{Acknowledgments}

The field work necessary to carry out this study was conducted as part of the management activities of the "Nomentum" nature reserve promoted by the Protected Areas Service (Dept. IV) of the Città metropolitana di Roma Capitale. We wish to thank the Park manager Massimo Fabiani, the operators of the "Nomentum" nature reserve (Christian Falappa, Laura Di Sisto, Luigi Nieri, Rolando Perfetti which support us during the field sampling. Davide Brocchieri and Stefano Doglio (SRSN - Società Romana di Scienze Naturali), Massimo Brunelli provided useful data. Thanks to Pierangelo Crucitti for making available the BioLazio database of the SRSN. Part of the work was part of a degree thesis: we thank prof. Marco Cosimo Simeone (University of Tuscia, Viterbo), for his availability and kindness.

$\mathrm{CB}, \mathrm{FM}, \mathrm{GD}, \mathrm{VC}$ defined the atlas design, carried out the field sampling and performed the statistical analyses, VB developed the species maps. All the authors discussed the results and commented on the manuscript. An anonymous reviewer (and Editor) provided useful comments and suggestions which improved the first draft of the manuscript. 


\section{REFERENCES}

AA. VV., 1999 - Parco Trentani: un laboratorio ambientale. Opuscolo divulgativo realizzato a cura dell'Associazione il Pineto e dalla Scuola media Aldo Moro (Tor Lupara-Mentana) e patrocinato dalla Provincia di Roma e dal Comune di Mentana. Mentana, Tipolitografica Marini.

Araújo M. B., Thuiller W., Williams P. H. \& Reginster I., 2005 - Downscaling European species atlas distributions to a finer resolution: implications for conservation planning. Global Ecology and Biogeography, 14: 17-30.

Arca E., Battisti C. \& Fraticelli F., 2012 - Area-effect in breeding bird communities occurring in an archipelago of urban holm oak fragments (Rome, Central Italy). Vie et Milieu, 62: 159-164.

Baccetti N., Fracasso G. \& Commissione Ornitologica Italiana, 2019 Checklist CISO-COI degli Uccelli Italiani. <https://www.ciso-coi. it/coi/checklist-ciso-coi-degli-uccelli-italiani/>

Battisti C., 2001 - Comunità ornitiche e frammentazione ambientale: dati dalle riserve naturali "Nomentum" e "Macchia di Gattaceca e del Barco" (Roma, Italia centrale). Rivista Italiana di Ornitologia, 71: 115-123.

Battisti C., 2006 - Fauna. In: Piano di Assetto. Riserva Naturale Nomentum. Quadro Conoscitivo. AA. VV. Provincia di Roma, Regione Lazio, Comune di Mentana, Comune di Fonte Nuova: 76-96.

Battisti C., Zapparoli M., Bianconi R. \& Lorenzetti E., 2003 - Analisi dei patterns di abbondanza di specie ornitiche sensibili in paesaggi frammentati (Italia centrale): una lettura dei dati in chiave ecologica e di pianificazione. Avocetta, Journal of Ornitology, 27: 56.

Battisti C., Lorenzetti E. \& Frank B., 2004 - L'effetto area su comunità ornitiche di frammenti forestali (Italia centrale): evidenze dai diagrammi rango/frequenza. XIV Congresso Nazionale di Ecologia, Siena, 4-6/10/2004. Riassunti: 70.

Battisti C., Luiselli L., Frank B. \& Lorenzetti E., 2009 - Should fragment area reduction be considered a stress for forest bird assemblages? Evidence from diversity/dominance diagrams. Community Ecology, 10: 189-195.

Battisti C., Giardini M., Marini F., Di Rocco L., Dodaro G. \& Vignoli L., 2017 - Diversity metrics, species turnovers and nestedness of bird assemblages in a deep karst sinkhole. Israel Journal of Ecology and Evolution, 63 (2): 8-16.

Battisti C., Dodaro G. \& Vannuccini M., 2020 - A fine-grained bird Atlas as tool for spatial monitoring: a case study from a remnant wetland during the breeding period (Torre Flavia, central Italy). Rivista Italiana di Ornitologia - Research in Ornithology, 90 (1): 41-50.

Berg A., Wretenberg J., Żmihorski M., Hiron M. \& Pärt T., 2015 Linking occurrence and changes in local abundance of farmland bird species to landscape composition and land-use changes. Agriculture, Ecosystems \& Environment, 204: 1-7.

Bianconi R., Battisti C. \& Zapparoli M., 2003 - Pattern of richness, abundance and diversity of four interior bird species in a hilly landscape in Central Italy: a contribution to assess their sensitivity to habitat fragmentation. Journal of Mediterranean Ecology, 4: 37 44.

Bibby C. J., Burgess N. D., Hill D. A. \& Mustoe S. H., 2000 - Bird census techniques. Second edition. Academic press, London.

Blair R. B., 2001 - Birds and butterflies along urban gradients in two ecoregions of the United States: is urbanization creating a homogeneous fauna? In: Biotic homogenization. Lockwood J. L. \& McKinney M. L. (eds.). Springer, The Netherlands.

Blair R. B., 2004 -The effects of urban sprawl on birds at multiple levels of biological organization. Ecology and Society, 9 (5), 2.

Blair R. B. \& Johnson E. M., 2008 - Suburban habitats and their role for birds in the urban-rural habitat network: points of local invasion and extinction? Landscape Ecology, 23: 1157-1169.

Blasi, C. 1994 - Fitoclimatologia del Lazio. Fitosociologia, 27: 151175.

Brambilla M., 2019 - Six (or nearly so) big challenges for farmland bird conservation in Italy. Avocetta, 43: 101-113.

Brunelli M., Sarrocco S., Corbi F., Sorace A., Boano A., De Felici S., Guerrieri G., Meschini A. \& Roma S. (eds.), 2011 - Nuovo atlante degli uccelli nidificanti nel Lazio. Edizioni ARP (Agenzia Regionale Parchi), Roma.
Brunelli M., Cento M., De Santis E., Savo E. \& Sorace A., 2016 Atlante degli uccelli nidificanti nella Riserva Naturale Regionale Montagne della Duchessa e nelle aree limitrofe (Lazio, Italia centrale). Alula, 23 (1-2): 35-82.

Buccomino G., Lerzio M. \& Leporatti M. L., 2017 - Contributo alla conoscenza della Flora vascolare della Riserva naturale di Nomentum (Lazio). Acta Plantarum Notes, 5: 86-102.

Būhning-Gaese K., 1997 - Determinants of avian species richness at different spatial scales. Journal of Biogeography, 24 (1): 49-60.

Calvi G., Campedelli T., Tellini Florenzano G. \& Rossi P., 2018 - Evaluating the benefits of agri-environment schemes on farmland bird communities through a common species monitoring programme. A case study in northern Italy. Agricultural Systems, 160: 60-69.

Campedelli T., Buvoli L., Bonazzi P., Calabrese L., Calvi G., Celada C., Cutini S., De Carli E., Fornasari L., Fulco E., La Gioia G., Londi G., Rossi P., Silva L. \& Tellini Florenzano G., 2012 - Andamenti di popolazione delle specie comuni nidificanti in Italia: 2000-2011. Avocetta, 36 (1): 121-143.

Ceccarelli P. P., GelliniS. \& Londi G., 2019 - Atlante degli uccelli nidificanti nel Parco nazionale delle Foreste casentinesi, Monte Falterona e Campigna (2012-2017). Parco nazionale delle Foreste casentinesi.

Connor E. F. \& McCoy E. D., 1979 - The statistics and biology of the species-area relationship. The American Naturalist, 113: 791833.

Crooks K. R., Suarez A. V. \& Bolger D. T., 2004 - Avian assemblages along a gradient of urbanizationin a highly fragmented landscape. Biological Conservation, 115: 451-462.

Crucitti P., Bubbico F., Bucceddi S. \& Rotella G., 2000 - Il Bosco Trentani 1. Riferimenti normativi, inquadramento geologico e geomorfologico. Annali Associazione Nomentana di Storia e Archeologia, n.s., 1: 69-71.

Crucitti P., Bubbico F., Bucceddi S. \& Ciccuzza D., 2001 - Il Bosco Trentani 2. Condizioni bioclimatiche e assetto della vegetazione. Annali Associazione Nomentana di Storia e Archeologia, n.s., 2: $72-74$.

Crucitti P., Bubbico F., Bucceddi S. \& Cavalieri C., 2003 - Il Bosco Trentani 4. Elenco preliminare delle specie della malacofauna terrestre. Annali Associazione Nomentana di Storia e Archeologia, n.s., 4: 108-110.

Crucitti P., Bubbico F., Bucceddi S. \& Chiné A., 2004a - Gli Anfibi e i Rettili del "Bosco Trentani" (Fonte Nuova e Mentana, Roma). Atti Società italiana di Scienze naturali e del Museo civico di Storia naturale di Milano, 145 (1): 3-18.

Crucitti P., Bubbico F., Bucceddi S. \& Vigna Taglianti A., 2004b Il Bosco Trentani 5. Uno sguardo preliminare all'entomofauna. Annali Associazione Nomentana di Storia e Archeologia, n.s., 5: 41-46

Crucitti P., Bubbico F., Bucceddi S \& Tringali L., 2005 - Il Bosco Trentani 6. Considerazioni sulle faune vertebrate (Anfibi, Rettili, Mammiferi). Annali Associazione Nomentana di Storia e Archeologia, n.s., 6: 64-69.

Crucitti P. \& Bufalieri C., 2012 - L'erpetofauna della Campagna Romana tra la Riserva Naturale della Marcigliana ed i Monti Cornicolani: revisione dei dati. Atti del Museo Civico di Storia Naturale di Trieste, 55: 69-89.

Crucitti P., 2013a - L'Arcipelago Mentanese-Cornicolano. Paesaggi frammentati della Campagna Romana. Bollettino della Società Geografica Italiana, Roma, Serie XIII, VI: 239-263.

Crucitti P., Amori G., Battisti C. \& Giardini M., 2013b - Check-list degli Anfibi, Rettili, Uccelli e Mammiferi dell'area "arcipelago mentanese-cornicolano" (Campagna Romana, Lazio). Bollettino del Museo Civico di Storia Naturale di Verona, 37 (Botanica Zoologia): 29-46.

Crucitti P., Brocchieri D., Bubbico F., Castelluccio P., Emiliani F., Francioni G. \& Tringali L., 2015 - Check-list di gruppi selezionati dell'entomofauna dell'area "Arcipelago Mentanese-Cornicolano" (Lazio). Bollettino della Società Entomologica Italaliana, 147: 3-29.

Deconchat M. \& Balent G., 2001 - Vegetation and bird community dynamics in fragmented coppice forests. Forestry, 74 (2): 105118. 
del Río M., Condés S. \& Pretzsch H., 2014 - Analyzing size-symmetric vs. size-asymmetric and intra-vs. inter-specific competition in beech (Fagus sylvatica L.) mixed stands. Forest Ecology and Management, 325: 90-98.

Devictor V., Julliard R., Couvet D., Lee A. \& Jiguet F., 2007 - The functional homogenization effect of urbanization on bird communities. Conservation Biology, 21: 741-51.

Devictor V., Julliard R., Clavel J., Jiguet F., Lee A., \& Couvet D., 2008 Functional biotic homogenization of bird communities in disturbed landscapes. Global Ecology and Biogeography, 17: 252261.

Doglio S., Malori M. \& Crucitti P., 2013 - Nuovi dati sulla erpetofauna dell'area "arcipelago mentanese-cornicolano" (Lazio). In: Atti IX Congresso Nazionale della Societas Herpetologica Italica (BariConversano, 26-30 settembre 2012). Scillitani G., Liuzzi C., Lorusso L., Mastropasqua F., Ventrella P. (eds.). Pineta, Conversano (Bari): 114-119.

Donald P. F. \& Fuller R. J., 1998 - Ornithological atlas data: a review of uses and limitations. Bird study, 45: 129-145.

Dytham C., 2011 - Choosing and using statistics: a biologist's guide. John Wiley \& Sons, New York.

Filippi-Codaccioni O., Devictor V., Clobert J. \& Julliard R., 2008 - Effects of age and intensity of urbanization on farmland bird communities. Biological Conservation, 141: 2698-2707.

Fornasari L., Londi G., Buvoli G., Tellini Florenzano G., La Gioia G., Pedrini P., Brichetti P. \& de Carli E. (eds.), 2010 - Distribuzione geografica e ambientale degli uccelli comuni nidificanti in Italia, 2000-2004 (dati del progetto MITO2000). Avocetta, 34 (2): 5-224.

Frank B. \& Battisti C., 2005 - Area effect on bird communities, guilds and species in a highly fragmented forest landscape of Central Italy. Italian Journal of Zoology, 72 (4): 297-304.

Giardini M., 2004 - Check-list degli Uccelli dei Monti Cornicolani (Roma, Italia centrale). Uccelli d'Italia, 29: 60-78.

Giardini M. \& Battisti C., 2012 - Gli uccelli dei monti Cornicolani. In: Sant'Angelo romano (Monti Cornicolani, Roma). Un territorio ricco di storia e di natura. Giardini M. (ed.). Comune di Sant'Angelo romano, Regione Lazio, Assessorato Ambiente e Sviluppo sostenibile, Grafica Ripoli, Tivoli: 190-202.

Gregory R. D., van Strien A., Vorisek P., Mayling A. W. G., Noble D. G., Foppen R. P. B. \& Gibbons D. W., 2005 - Developing indicators for European birds. Philosophical Transactions of The Royal Society, B 360: 269-288.

Gregory R. D. \& van Strien A., 2010 - Wild bird indicators: using composite population trends of birds as measures of environmental health. Ornithological Science, 9: 3-22.

Guetté A., Gaüzère P., Devictor V., Jiguet F. \& Godet L., 2017 - Measuring the synanthropy of species and communities to monitor the effects of urbanization on biodiversity. Ecological Indicators, 79: 139-154.

Guidi A., 2004 - Flora e vegetazione. In: Piano di Assetto. Riserva Naturale Nomentum. Quadro Conoscitivo. AA. VV. Provincia di Roma - Regione Lazio, Comune di Mentana, Comune di Fonte Nuova: 9-30.

Guidi A. \& Battisti C., 2010 - Avifauna nidificante nella Riserva naturale "Monte Catillo" (Tivoli, Italia centrale): check-list e atlante. Alula, 17: 59-87.

Gustin M., Brambilla M. \& Celada, C., 2010 - Valutazione dello Stato di Conservazione dell'avifauna italiana. Volume II. Passeriformes. Ministero dell'Ambiente e della Tutela del Territorio e del Mare, Lega Italiana Protezione Uccelli (LIPU), Parma.

Gustin M., Nardelli R., Brichetti P., Battistoni A., Rondinini C. \& Teofili C. (eds.), 2019 - Lista Rossa IUCN degli uccelli nidificanti in Italia 2019. Comitato Italiano IUCN e Ministero dell'Ambiente e della Tutela del Territorio e del Mare, Roma.

Havlíček J., Riegert J., Bandhauerová J., Fuchs R. \& Šálek M., 2021 Species-specific breeding habitat association of declining farmland birds within urban environments: conservation implications. Urban Ecosyst, 24 (3): 1259-1270. <https://doi.org/10.1007/s11252-02101111-9>

James F. C. \& Shugart, H. H., 1970 - A quantitative method of habitat description. Audubon Field Notes, 24: 727-736.
Johnston R. F., 2001 - Synanthropic birds of North America. In: Avian Ecology in an Urbanizing World. Marzluff J. M., Bowman R. \& Donnelly R. (eds.). Kluwer Academic Publishers, Norwell, MA: 49-67.

La Mantia T., Bonaviri L. \& Massa B., 2014 - Ornithological communities as indicators of recent transformations on a regional scale: Sicily's case. Avocetta, 38: 67-81.

Lorenzetti E. \& Battisti C., 2005 - Indicatori faunistici nella pianificazione delle aree protette. Estimo e Territorio, 68 (1): 16-24.

Lorenzetti E. \& Battisti C., 2006 - Area as component of habitat fragmentation: corroborating its role in breeding bird communities and guilds of oak wood fragments in Central Italy. Revue d'Ecologie (Terre Vie), 61: 53-68.

Lorenzetti E. \& Battisti C., 2007 - Nature reserve selection on forest fragments in a suburban landscape (Rome, Central Italy): indications from a set of avian species. Landscape Research, 32: 5778.

Magurran A., 2004 - Measuring Biological Diversity. Blackwell.

Marini F., Battisti C., Ranchelli E., Ciambotta M. \& Ventura A., 2014 L'avifauna nidificante nella Riserva naturale di Monte Soratte (Lazio, Italia centrale): check-list, status di conservazione e atlante locale. Bollettino del Museo Civico di Storia Naturale di Verona, Botanica Zoologia, 38: 161-179.

Mattioli W., Pinelli A., Filibeck, G., Portoghesi L., Scoppola A. \& Corona P., 2008 - Relazioni tra gestione selvicolturale, tipo forestale e diversità floristica in cedui castanili.Forest@-Journal of Silviculture and Forest Ecology, 5(2): 136.

McKinney M. L., 2006 - Urbanization as a major cause of biotic homogenization. Biological Conservation, 127: 247-260.

Mortelliti A., Fagiani S., Battisti C., Capizzi D. \& Boitani L., 2010 Independent effects of habitat loss, habitat fragmentation and structural connectivity on forest-dependent birds. Diversity and distribution, 16 (6): 941-951.

Muratore S., Monaco E., Piroli R. \& Sorace A., 2018 - L'avifauna nidificante in un mosaico agricolo dell'Italia centrale: la Riserva naturale di Macchiatonda (Lazio). Alula, 25 (1-2): 81-97.

Nardelli R., Andreotti A., Brambilla M., Brecciaroli B., Celada C., Dupré E., Gustin M., Longoni V., Pirrello S., Spina F., Volponi S. \& Serra L., 2015 - Rapporto sull'applicazione della Direttiva $147 / 2009 / \mathrm{CE}$ in Italia: dimensione, distribuzione e trend delle popolazioni di uccelli (2008-2012). ISPRA, MATTM, Roma.

Paolini A. \& Capecchi P., 2004 - Aspetti geologici e idrogeologici. In: Piano di Assetto. Riserva Naturale Nomentum. Quadro Conoscitivo. AA. VV. Provincia di Roma, Regione Lazio, Comune di Mentana, Comune di Fonte Nuova: 59-75.

Quatrini A., Scarfò F. \& Zapparoli M., 2012 - Atlante degli uccelli nidificanti nella Riserva Naturale Regionale del Lago di Vico (Lazio, Viterbo). Alula, 19: 97-163.

Rafe R. W., Usher M. B. \& Jefferson R. G., 1985 - Birds on reserves: the influence of area and habitat on species richness. Journal of Applied Ecology, 22: 327-335.

Rete Rurale Nazionale \& Lipu, 2021 - Farmland Bird Index nazionale e andamenti di popolazione delle specie in Italia nel periodo 20002020. Lipu, Parma.

Rosati L., Fipaldini M., Marignani M. \& Blasi C., 2010 - Effects of fragmentation on vascular plant diversity in a Mediterranean forest archipelago. Plant Biosystems, 144 (1): 38-46.

Sarrocco S., Battisti C., Brunelli M., Calvario E., Ianniello L., Sorace A., Teofili C., Trotta M., Visentin M. \& Bologna M. A., $2002-$ L'avifauna delle aree naturali protette del Comune di Roma gestite dall'Ente Roma Natura. Alula, 9: 3-31.

Shannon C. E. \& Weaver W., 1949 - The mathematical theory of communication. The University of Illinois Press, Urbana.

Seress G. \& Liker A., 2015 - Habitat urbanization and its effects on birds. Acta Zoologica Academiae Scientiarum Hungaricae, 61: 373-408.

Sorace A., Trotta M., Mirabile M., Lorenzetti E., Monti P., Petrella S., Taffon D., Teofili C. \& Battisti C., 2017 - Atlante degli uccelli nidificanti della Riserva Naturale Regionale di Decima-Malafede. Dati faunistici per la gestione di un'area protetta. ISPRA, Quaderni, Natura e Biodiversità, 9/2018, Roma. 
Sorace A., De Santis E., Falasconi R., Monterosso G., Savo E. \& Somaschini A. (eds.), 2019 - Atlante degli Uccelli nidificanti e svernanti nel Parco Naturale Regionale di Veio. Edizioni Parco di Veio.

SPSS Inc., 2003 - SPSS for Windows. Release 13.0 (1 Sep 2004), Leadtools (c), Lead Technologies Inc.

Stein A., Gerstner K. \& Kreft H., 2014 - Environmental heterogeneity as a universal driver of species richness across taxa, biomes and spatial scales. Ecology letters, 17: 866-880.

Sutherland W. J., 2006 - Ecological Census Techniques. Blackwell, London.

Szép T., Nagy K., Nagy Z., \& Halmo G., 2012 - Population trends of common breeding and wintering birds in Hungary, decline of longdistance migrant and farmland birds during 1999-2012. Ornis Hungarica, 20: 13-63.

Taffon D. \& Battisti C., 2003 - L'Atlante locale degli uccelli nidificanti di un settore della provincia di Roma (area Mentanese-Cornicolana): considerazioni faunistiche, ecologiche, applicative. Alula, 10: $3-48$.

Taffon D., Battisti C. \& Giucca F., 2011 - Atlante degli uccelli nidificanti nel Parco Regionale dell'Appia Antica. Gangemi Editore, Roma.

Tews J., Brose U., Grimm V., Tielbörger K., Wichmann M. C., Schwager M. \& Jeltsch F., 2004 - Animal species diversity driven by habitat heterogeneity/diversity: the importance of keystone structures. Journal of Biogeography, 31: 79-92.

Vannicelli Casoni L., 2004 - Aspetti climatici. In: Piano di Assetto. Riserva Naturale Nomentum. Quadro Conoscitivo. AA. VV. Provincia di Roma, Regione Lazio, Comune di Mentana, Comune di Fonte Nuova: 97-114.

Velatta F., Lombardi G. \& Sergiacomi U., 2016 - Bird Homogenization at regional scale (Umbria, central Italy): a lack of evidence for a change in the 2001-2014 period. Avocetta, 40: 1-10.

\section{SUPPORTING INFORMATION / INFORMAZIONI \\ SUPPLEMENTARI}

Additional supporting information may be found online for this article. / Per questo articolo sono disponibili informazioni supplementari online.

S1 - Maps of the single breeding bird species. / Mappe delle singole specie di uccelli nidificanti. 